\title{
Disordered Eating and Exercise Dependence in Endurance Athletes
}

\author{
Bernd Zeulner ${ }^{*}$, Heiko Ziemainz ${ }^{2}$, Christian Beyer ${ }^{3}$, Matthias Hammon ${ }^{4}$, Rolf Janka4 \\ ${ }^{1}$ Friedrich-Alexander-University Erlangen-Nürnberg (FAU), Erlangen, Germany \\ ${ }^{2}$ Institute of Sport Science and Sport, Friedrich-Alexander-University Erlangen-Nürnberg (FAU), Erlangen, \\ Germany \\ ${ }^{3}$ Department of Internal Medicine 3 for Rheumatology and Immunology, Friedrich-Alexander-University \\ Erlangen-Nürnberg (FAU), Erlangen, Germany \\ ${ }^{4}$ Department of Radiology, Friedrich-Alexander-University Erlangen-Nürnberg (FAU), Erlangen, Germany \\ Email: "bernd.zeulner@gmx.de, heiko.ziemainz@sport.uni-erlangen.de, christian.beyer@uk-erlangen.de, \\ matthias.hammon@uk-erlangen.de,rolf.janka@uk-erlangen.de
}

Received 24 October 2015; accepted 2 May 2016; published 6 May 2016

Copyright (C) 2016 by authors and Scientific Research Publishing Inc.

This work is licensed under the Creative Commons Attribution International License (CC BY).

http://creativecommons.org/licenses/by/4.0/

(c) (i) Open Access

\begin{abstract}
Background: The goal of this study was to assess the prevalence of disordered eating and exercise dependence among elite and amateur endurance athletes, both male and female, and to find out whether there was an association between disordered eating and exercise addiction in these athletes. Methods: 1031 participants of major German endurance events (745 male, 286 female, 528 elite athletes and 503 hobby athletes) with a mean age of $41.6 \pm 10.7$ years old completed a set of questionnaires, including the SCOFF questionnaire and the Exercise Addiction Inventory (EAI). Results: A rate of $\mathbf{1 8 . 9 \%}$ of the athletes surveyed were at risk for developing an eating disorder, slightly higher than that in the normal population, and $2.7 \%$ had the potential to develop an exercise addiction. There was a significant correlation between exercise addiction and eating disorders. No gender difference related to the probability of developing an eating disorder or an exercise addiction, nor a difference between elite or amateur athletes was found. Exercise addiction and eating disorders showed a significant correlation.
\end{abstract}

\section{Keywords}

Athlete's Triad, Running Addiction, Anorexia Athletica, Commitment to Running, Running, Cycling, Triathlon

\section{Introduction}

Endurance sports, including long distance running, cycling and triathlon, are associated with many positive phy-

${ }^{*}$ Corresponding author.

How to cite this paper: Zeulner, B., Ziemainz, H., Beyer, C., Hammon, M., \& Janka, R. (2016). Disordered Eating and Exercise Dependence in Endurance Athletes. Advances in Physical Education, 6, 76-87. http://dx.doi.org/10.4236/ape.2016.62009 
siological effects, such as improvement in aerobic capacity (Saltin et al., 1968; Kasch et al., 1973), cardio-protection (Ascensao et al., 2007; Bo et al., 2014), treatment of Type I and Type II diabetes (Palermo et al., 2014; Karstoft \& Pedersen, 2015; Roberts \& Taplin, 2015; Ryninks et al., 2015; Yoon et al., 2015), athletic body composition (Pollock et al., 1975), and bone density (Kemmler et al., 2006; Winzenberg et al., 2006; Kemmler et al., 2015). In addition, a large body of evidence demonstrates specific benefits of endurance sports on psychological health, including protection from depressive disorders, enhanced self-esteem, an improved feeling of wellness and an increased sense of personal control (Leonardson, 1977; Greist et al., 1978; Lion, 1978; Greist et al., 1979; Jorgenson \& Jorgenson, 1979). In this context, NICE (National Institute for Health and Care Excellence, London, UK) guidelines suggest that regular athletic activities (e.g., 3 times a week for 45 - 60 minutes) for 10 - 14 weeks can improve mild to moderate depression (Nice-Guidelines, 2009; Kim et al., 2015). A number of authors even assume that the effect of endurance exercise is comparable to pharmacological and behavioral therapy (Dirmaier et al., 2010).

Despite these positive effects, sports activities have been determined a risk factor for the development of eating disorders. In this context, eating disorders may include all kinds of pathological eating behaviours that impact patient's health in a negative way such as anorexia nervosa, bulimia nervosa and binge-eating disorders. Performance sports with an emphasis on aesthetic body appearance enhancement, sports organized according to weight categories and those in which a lower body weight may raise performance, especially endurance sports, seem to be associated with risk factors (Sundgot-Borgen \& Torstveit, 2004; Nice-Guidelines, 2009; Le Page, 2010; MayoClinicStaff, 2010; Busanich, 2014; Maraz et al., 2015). Although eating disorders in sports have been studied as early as 1986 (Wheeler et al., 1986), the results from the existing studies are conflicting. While various groups have found a two-fold increase in the prevalence of developing eating disorders among sports participants (Thopson, 2007; Chapman \& Woodman, 2015; Wheeler et al., 1986; Sundgot-Borgen \& Torstveit, 2004; Torstveit \& Sundgot-Borgen, 2005; Glazer, 2008; Hoch et al., 2009), others have not observed any differences among people exposed to regular exercise versus controls (Fulkerson et al., 1999; Smolak et al., 2000). Of note, two reports even identified a higher incidence of eating disorders among the non-sport control group (Rosendahl et al., 2009; Martinsen et al., 2010). Major variations in study cohorts, design and goals most likely account for these striking differences. This includes evaluating only young women, examining athletes engaging in all kinds of sports, using unique measurement instruments, often not even validated questionnaires, assessing a very small number of participants or looking at just elite athletes (Sundgot-Borgen \& Larsen, 1993; Johnson et al., 1999; Hoch et al., 2007; Lejoyeux et al., 2008; Hoch et al., 2009; Rosendahl et al., 2009; Busanich, 2014; Chapman \& Woodman, 2015). There is a lack of data specifically on male subjects.

Many sports, especially endurance sports, are associated with exercise addiction, which means a pathological behaviour regarding to body workout. Most authors classify sports addiction as a behavioural and mental disorder comparable to shopping or internet addiction (Griffiths et al., 2005; Edmunds et al., 2006). General criteria for addiction like repeatedly performing of a given behaviour despite any negative consequences are used for diagnosis. Many authors have even suggested that people participating in endurance sports-especially running -are at very high risk for developing such an addiction (Salmon, 1991), whereas others have predicted only a very low number of exercise-dependent athletes (de Coverley Veale, 1987; Edmunds et al., 2006). There are very heterogeneous data relating to gender differences with regards to exercise dependence which may be because of different questionnaires measuring dissimilar aspects of exercise addiction (Weik \& Hale, 2009).

Taking the lack of available data, especially from endurance sports, and the assumption that endurance sports might be a risk factor for eating disorders into account, the prevalence of disordered eating and exercise dependence for endurance athletes, both male and female, was assessed. Moreover, the objective was to investigate a potential association between disordered eating and exercise addiction in these athletes.

\section{Methods}

\subsection{Recruitment}

Participants were recruited at six supra-regional endurance competitions in Germany between 2007 and 2008 , composed of two running, two triathlon and two cycling events. One of each was an event for elite athletes and one an event for amateur competitors. In detail, the individual events were a $10 \mathrm{~km}$ hobby run without timing, the German marathon championships, an amateur-oriented Olympic distance triathlon (1.5 km swim, $40 \mathrm{~km}$ bike, $10 \mathrm{~km}$ run), the German long distance triathlon championships (3.8 km swim, $180 \mathrm{~km}$ bike, $42 \mathrm{~km}$ run), an 
amateur bike ride with various tracks without timing and a bike marathon (multiple tracks up to $250 \mathrm{~km}$ ). After the event, athletes were randomly asked to participate in the study and to fill out the questionnaires after the events in the finisher areas. For participating in our study it was obligatory to speak and understand German language. All questionnaires were anonymized. The study was subject to conditions of the Declaration of sinki (Revision, 2008) and all participants gave their informed consent (Williams, 2008).

\subsection{Instruments}

The questionnaire included data pertaining to general socio-demographic status, such as age, height, weight, gender, marital status, working status (working, in vocational training/student, not working), educational level (less than 10 years of school, at least 10 years of school), years practicing endurance exercise (ey), training hours per week (thw), number of training units per week (tuw), type of training (alone or in a group) and the type of sporting activity practiced.

The two national championships (long distance triathlon and marathon) and the bike marathon were defined as elite events and the other three events which focus on amateur athletes as hobby events.

Two screening questionnaires were used to assess exercise dependence (Exercise Addiction Inventory; EAI (Griffiths et al., 2005)) and disordered eating (SCOFF (Morgan et al., 1999)); German version (Holling et al., 2007). The EAI consists of 6 screening questions representing a single component assessing salience, conflict, mood modification, tolerance, withdrawal, and relapse associated with exercising, based on Brown's general components of addiction (Brown, 1993). All items were scored on a five-point Likert scale ( 1 = strongly disagree to $5=$ strongly agree) and coded so that high scores reflect attributes of addictive exercise behaviour. The EAI showed robust and concurrent validity with the Obligatory Exercise Questionnaire (OEQ) (Pasman \& Thomson, 1988) $(r=0.80)$ and the Exercise Dependence Scale (EDS) (Hausenblas \& Symons Downs, 2001) ( $r$ $=0.81$ ). A cut-off score of 24 or more identifies individuals considered at risk for exercise addiction. The EAI was translated by a professional translator for medical texts and then verified by all authors. Factor analysis showed one dimensionality also in the German version. The Exercise Addiction Inventory can be found in Table 1.

The SCOFF is a widely-used and well-validated (Hill et al., 2009) screening tool for eating disorders. It contains five questions addressing core features of anorexia nervosa and bulimia nervosa. A cut-off score of 2 is applied to identify probable cases of eating disorders. The single items are:

$\mathrm{S} \quad$ Do you make yourself SICK (vomit) because you feel uncomfortably full?

C Do you worry that you have lost CONTROL over how much you eat?

O Have you recently lost more than ONE stone (15 pounds) in a 3 month period?

F Do you believe yourself to be FAT when others say you are thin?

F Would you say that FOOD dominates your life?

In primary care, the SCOFF showed a sensitivity of $84.6 \%$ and a specificity of $89.6 \%$, detecting all cases of anorexia nervosa and bulimia nervosa and seven of nine eating disorders not otherwise specified (Hill et al., 2009).

Table 1. The exercise addiction inventory.

\begin{tabular}{|c|c|c|c|c|c|}
\hline & $\begin{array}{l}\text { Strongly } \\
\text { disagree }\end{array}$ & & $\begin{array}{l}\text { Neither agree nor } \\
\text { disagree }\end{array}$ & & $\begin{array}{l}\text { Strongly } \\
\text { agree }\end{array}$ \\
\hline Exercise is the most important thing in my life. & 1 & 2 & 3 & 4 & 5 \\
\hline $\begin{array}{l}\text { Conflicts have arisen between me and my family and/or my partner } \\
\text { about the amount of exercise I do. }\end{array}$ & 1 & 2 & 3 & 4 & 5 \\
\hline $\begin{array}{l}\text { I use exercise as a way of changing my mood (e.g. to get a buzz, to } \\
\text { escape etc.). }\end{array}$ & 1 & 2 & 3 & 4 & 5 \\
\hline Over time I have increased the amount of exercise I do in a day. & 1 & 2 & 3 & 4 & 5 \\
\hline If I have to miss an exercise session I feel moody and irritable. & 1 & 2 & 3 & 4 & 5 \\
\hline $\begin{array}{l}\text { If I cut down the amount of exercise I do, and then start again, I always } \\
\text { end up exercising as often as I did before. }\end{array}$ & 1 & 2 & 3 & 4 & 5 \\
\hline
\end{tabular}


Based on the participants' self-reported height and weight, the BMI $\left(\mathrm{kg} / \mathrm{m}^{2}\right)$ was calculated. For the purpose of the present study, BMI was recorded into four categories according to WHO recommendations: underweight $\left(\right.$ BMI $\left.<18.49 \mathrm{~kg} / \mathrm{m}^{2}\right)$, normal weight (BMI $18.5-24.99 \mathrm{~kg} / \mathrm{m}^{2}$ ), overweight $\left(\right.$ BMI $>25-29.99 \mathrm{~kg} / \mathrm{m}^{2}$ ) and obesity $\left(\mathrm{BMI}>30 \mathrm{~kg} / \mathrm{m}^{2}\right)(\mathrm{WHO}, 2012)$.

\subsection{Statistical Analysis}

PASW 18 (SPSS Inc, Chicago, Il, USA) was used for statistical analyses. Results are expressed as mean values (SD) for continuous values and absolute numbers $(\mathrm{N})$ and percentages (\%) for categorical data. For the main analyses the samples were divided into SCOFF positive ( $>2$ positive answers) and SCOFF negative $(<2$ positive answers) participants. The independent sample t-test was employed to compare continuous variables and the $\chi^{2}$ test was used to evaluate categorical variables. An alpha level of 0.05 was adopted for all analyses.

\section{Results}

\subsection{Description of the Sample}

1187 participants were asked to take part in the study. 1093 (92.1\%) answered the questionnaire (men 788, woman 305, NN 26, with a mean age of $41.2 \pm 11.2$ years). All people were Caucasian Whites speaking German as their mother language. The mean BMI was $23.3 \pm 2.8 \mathrm{~kg} / \mathrm{m}^{2}\left(23.1 \pm 2.9 \mathrm{~kg} / \mathrm{m}^{2}\right.$ elite athletes, $23.6 \pm 2.6 \mathrm{~kg} / \mathrm{m}^{2}$ hobby athletes). Study participants had exercised on average for $13.0 \pm 10.2$ years (ey), reported $8.3 \pm 4.6$ hours of training a week (thw) and $4.5 \pm 2.3$ training units per week (tuw). 871 participants (83.3\%) had spent at least 10 years at school and 177 (16.7\%) less than 10 years, NN 45. A majority of 931 (87.6\%) had a regular job, while $66(6.1 \%)$ participants were students or in vocational training and another 66 (6.1\%) were neither employed with a job nor training, NN 30. Elite athletes' thw was $8.7 \pm 4.3$ hours and tuw was $4.5 \pm 2.1$, and the corresponding numbers for hobby athletes were $7.7 \pm 4.9$ thw and $4.4 \pm 2.4$ tuw. While there was a significant difference in training hours per week between elite and hobby athletes $(\mathrm{t}=3.7, \mathrm{df}=1021 \mathrm{p}=0.000$ ), the numbers of training units between the two groups were similar $(t=0.3, d f=1013, p=0.791)$, suggesting that elite athletes spend more time in one training unit. Male athletes exercised $8.5 \pm 4.89$ thw and $4.4 \pm 2.3$ tuw, whereas females attained $7.5 \pm 4.2$ thw and $4.5 \pm 2.3$ tuw. There was a significant difference in thw between men and women $(\mathrm{t}=3.7, \mathrm{df}=1020, \mathrm{p}=0.000)$, but not in tuw $(\mathrm{t}=-0.3, \mathrm{df}=1012, \mathrm{p}=0.790)$.

Twenty participants were excluded because they were younger than 18 years old and one because they were older than 80 years old. 42 participants did not complete the SCOFF questionnaire and were excluded from further analyses. The final sample was comprised of 1031 participants (745 male, 286 female, 528 elite athletes and 503 hobby athletes) with a mean age of $41.6 \pm 10.7$ years.

\subsection{Prevalence of Disordered Eating Behaviour}

195/1031 (18.9\%) athletes obtained scores above the threshold value of the SCOFF for disordered eating behaviour ( $>2$ positive answers). The most commonly endorsed item was the question regarding whether food dominates the subject's life. The frequencies of positive answered items are shown in Table 2.

SCOFF-positive athletes were significantly younger (38.9 \pm 9.9 vs. $42.3 \pm 10.8$ years, $\mathrm{p}<0.001)$ and have a significantly higher BMI $\left(24.4 \pm 3.1\right.$ vs. $\left.23.1 \pm 2.6 \mathrm{~kg} / \mathrm{m}^{2}, \mathrm{p}<0.001\right)$. With respect to employment status, there were a significantly higher number of SCOFF-positive athletes in the group "in vocational training, student" than expected $(\mathrm{p}<0.001)$ (Table 3).

\section{Table 2. Positive answered items at the SCOFF questionnaire.}

\begin{tabular}{ccc}
\hline Would you say that food dominates your life? & Frequency & Percent agreement \\
\hline Do you worry that you have lost control over how much you eat? & 417 & 157 \\
Do you believe yourself to be fat when others say that you are thin? & 132 & $70.4 \%$ \\
Have you recently lost more than 15 pounds in a 3-month period? & $76.8 \%$ \\
Do you make yourself sick because you feel uncomfortably full? & 31 \\
\hline
\end{tabular}


Table 3. Differences between SCOFF positive and negative sample.

\begin{tabular}{ccccc}
\hline Characteristic & Sample/no answer & SCOFF positive & SCOFF negative & Analysis \\
all & 1031 & $195(18.9 \%)$ & $836(81.1 \%)$ & \\
Age (years) & 1031 & $(\mathrm{SD}=9.9)$ & $(\mathrm{SD}=10.8)$ & $\mathrm{t}=4.0, \mathrm{df}=1029, \mathrm{p}<0.001$ \\
BMI $\left(\mathrm{km} / \mathrm{m}^{2}\right)$ & $1026 / 5$ & 24.4 & 23.1 & $\mathrm{t}=5.8, \mathrm{df}=1024, \mathrm{p}<0.001$ \\
BMI-Categories & $1026 / 5$ & $(\mathrm{SD}=3.1)$ & $(\mathrm{SD}=2.6)$ & $\chi^{2}=49.5, \mathrm{df}=3, \mathrm{p}<0.001$ \\
Underweight & 17 & $2(11.8 \%)$ & $15(88.2 \%)$ & \\
Normal-weight & 790 & $117(14.8 \%)$ & $673(85.2 \%)$ & \\
Overweight & 196 & $57(29.1 \%)$ & $139(70.1 \%)$ & $\mathrm{T}=3.9, \mathrm{df}=997, \mathrm{p}<0.01$ \\
Obesity & 23 & $14(60.9 \%)$ & $9(39.1 \%)$ & 16.8 \\
EAI Score & $999 / 27$ & $(\mathrm{SD}=4.1)$ & $(\mathrm{SD}=3.9)$ & \\
EAI $\geq 24$ & $999 / 27$ & $172(17.7 \%)$ & $800(82.3 \%)$ & $\chi^{2}=9.3, \mathrm{df}=1, \mathrm{p}<0.01, \mathrm{Cramer} \mathrm{V}=0.56$ \\
Negative & 972 & $11(1.1 \%)$ & $16(1.6 \%)$ & \\
Positive & 27 & $173(19.4 \%)$ & $720(80.6 \%)$ & $\chi^{2}=17.2, \mathrm{df}=2, \mathrm{p}<0.001$ \\
Employment & $1016 / 15$ & $19(32.2 \%)$ & $40(67.8 \%)$ & \\
Working & 893 & $2(3.1 \%)$ & $62(96.9 \%)$ & \\
Vocational training, students & 59 & 64 & &
\end{tabular}

In addition, there was a significant difference in scoring the EAI-SCOFF-positive participants scored significantly higher $(18.0 \pm 4.1)$ than that were SCOFF negative $(16.8 \pm 3.9, \mathrm{p}<0.01)$. This difference can also be seen comparing the EAI-and SCOFF-positive/negative groups $\left(\chi^{2}=9.3\right.$, df $=1, \mathrm{p}<0.01$ ) (Table 3).

There was no difference found in gender and in the sport mainly practiced by the participants that were developing an eating disorder. The rate of SCOFF-positive participants was not higher in elite level athletes versus hobby athletes.

Neither training hours per week nor training sessions per week or exercise years had a significant influence on developing eating disorders. The level of education also exhibited no influence.

The in-test reliability was, as expected, low at Cronbach Alpha $=0.417$.

\subsection{Prevalence of Exercise Addiction}

In this study's sample, 27/999 participants who completed the EAI were observed to be at risk for developing exercise dependence resulting in a frequency of $2.7 \%$. The age distribution can be seen in Table 4.

EAI positive participants were significantly younger $(36.1 \pm 10.3$ vs. $41.7 \pm 10.7$ years, $\mathrm{p}<0.01)$ and were characterized by a higher number of training hours per week $(9.6 \pm 4.3$ vs. $8.2 \pm 4.6$ thw, p $<0.01)$ and training units per week ( $5.7 \pm 2.4$ vs. $4.5 \pm 2.3$ tuw, $\mathrm{p}<0.01)$.

EAI positive participants also scored significant higher on the SCOFF test $(1.3 \pm 0.9)$ versus EAI negatives $(0.8 \pm 0.9, \mathrm{p}<0.01)$; the risk for scoring SCOFF "positive" was significantly greater in the EAI positive group $\left(\chi^{2}=9.3, \mathrm{df}=1, \mathrm{p}<0.01\right)$ (Table 5). There is also a weak but highly significant correlation between EAI-Sum and SCOFF-Sum $(r=0.155, \mathrm{p}>0.01)$.

In relation to employment status, there were significantly more participants out of the "vocational training, student" group that scored EAI positive $\left(\chi^{2}=9.9, \mathrm{df}=2, \mathrm{p}<0.01\right)$.

EAI positive and EAI negative participants did not demonstrate any differences in the following variables: gender, BMI, exercise years, level of engaging in sports, sport mainly practiced and education. Moreover, there was no variation between runners and participants that engaged mainly in another sport.

In our study the EAI questionnaire showed a reliability of Cronbach Alpha $=0.588$.

\section{Discussion}

In the work presented here, the prevalence of disordered eating among endurance athletes was $18.9 \%$. Disordered 
Table 4. Age distribution among EAI positive subjects.

\begin{tabular}{|c|c|c|c|c|}
\hline & & & EAI negative & EAI positive \\
\hline \multirow{24}{*}{ Age group } & \multirow{2}{*}{$16-20$} & $\mathrm{~N}$ & 16 & 2 \\
\hline & & $\%$ within age group & $88.9 \%$ & $11.1 \%$ \\
\hline & \multirow{2}{*}{$21-25$} & $\mathrm{~N}$ & 45 & 2 \\
\hline & & $\%$ within age group & $95.7 \%$ & $4.3 \%$ \\
\hline & \multirow{2}{*}{$26-30$} & $\mathrm{~N}$ & 95 & 8 \\
\hline & & $\%$ within age group & $92.2 \%$ & $7.8 \%$ \\
\hline & \multirow{2}{*}{$31-35$} & $\mathrm{~N}$ & 120 & 6 \\
\hline & & $\%$ within age group & $95.2 \%$ & $4.8 \%$ \\
\hline & \multirow{2}{*}{$36-40$} & $\mathrm{~N}$ & 148 & 8 \\
\hline & & $\%$ within age group & $94.9 \%$ & $5.1 \%$ \\
\hline & \multirow{2}{*}{$41-45$} & $\mathrm{~N}$ & 189 & 5 \\
\hline & & $\%$ within age group & $97.4 \%$ & $2.6 \%$ \\
\hline & \multirow{2}{*}{$46-50$} & $\mathrm{~N}$ & 182 & 3 \\
\hline & & $\%$ within age group & $98.4 \%$ & $1.6 \%$ \\
\hline & \multirow{2}{*}{$51-55$} & $\mathrm{~N}$ & 73 & 6 \\
\hline & & $\%$ within age group & $92.4 \%$ & $7.6 \%$ \\
\hline & \multirow{2}{*}{$56-60$} & $\mathrm{~N}$ & 43 & 1 \\
\hline & & $\%$ within age group & $97.7 \%$ & $2.3 \%$ \\
\hline & \multirow{2}{*}{$61-65$} & $\mathrm{~N}$ & 24 & 1 \\
\hline & & $\%$ within age group & $96.0 \%$ & $4.0 \%$ \\
\hline & \multirow{2}{*}{$66-70$} & $\mathrm{~N}$ & 15 & 0 \\
\hline & & \% within age group & $100.0 \%$ & $0.0 \%$ \\
\hline & \multirow{2}{*}{$71-75$} & $\mathrm{~N}$ & 7 & 0 \\
\hline & & $\%$ within age group & $100.0 \%$ & $0.0 \%$ \\
\hline \multirow{2}{*}{\multicolumn{2}{|c|}{ Overall }} & $\mathrm{N}$ & 957 & 42 \\
\hline & & $\%$ & $95.8 \%$ & $4.2 \%$ \\
\hline
\end{tabular}

Table 5. Differences between EAI positive and negative sample.

\begin{tabular}{|c|c|c|c|c|}
\hline Characteristic & Sample/no answer & EAI positive & EAI negative & Analysis \\
\hline Age (years) & $999 / 32$ & $\begin{array}{c}36.1 \\
(\mathrm{SD}=10,3)\end{array}$ & $\begin{array}{c}41.7 \\
(\mathrm{SD}=10.7)\end{array}$ & $\mathrm{t}=2.7, \mathrm{df}=997, \mathrm{p}<0.01$ \\
\hline Training hours per week & $992 / 39$ & $\begin{array}{c}9.6 \\
(\mathrm{SD}=4.3)\end{array}$ & $\begin{array}{c}8.21 \\
(\mathrm{SD}=4.6)\end{array}$ & $\mathrm{t}=-1.5, \mathrm{df}=990, \mathrm{p}<0.01$ \\
\hline Training lessons per week & $985 / 46$ & $\begin{array}{c}5.7 \\
(\mathrm{SD}=2.4)\end{array}$ & $\begin{array}{c}4.5 \\
(\mathrm{SD}=2.3)\end{array}$ & $\mathrm{t}=-2.845, \mathrm{df}=983, \mathrm{p}<0.01$ \\
\hline SCOFF Score & $999 / 32$ & $\begin{array}{c}1.3 \\
(\mathrm{SD}=0.9)\end{array}$ & $\begin{array}{c}0.8 \\
(\mathrm{SD}=0.9)\end{array}$ & $\mathrm{t}=-3.0, \mathrm{df}=997, \mathrm{p}<0.01$ \\
\hline $\mathrm{SCOFF} \geq 2$ & $999 / 42$ & & & $\chi^{2}=9.3, \mathrm{df}=1, \mathrm{p}<0.01$ \\
\hline Positive & & $11(1.1 \%)$ & $172(17.2 \%)$ & \\
\hline Negative & & $16(1.6 \%)$ & $800(80.1 \%)$ & \\
\hline Employment & $985 / 46$ & & & $\chi^{2}=9.9, \mathrm{df}=2, \mathrm{p}<0.01$ \\
\hline Working & & $21(2.1 \%)$ & $846(85.9 \%)$ & \\
\hline Vocational training, students & & $5(0.5 \%)$ & $53(5.4 \%)$ & \\
\hline Not working & & $0.0 \%$ & $60(6.1 \%)$ & \\
\hline
\end{tabular}


eating is a major burden for public health with predominance in young female adults. Approximately two-thirds of young female adults are chronically on a diet or using alternative methods for weight reduction and every fifth woman reports attacks of hunger more than once monthly (Jacobi \& de Zwaan, 2006).

The existing literature on eating disorders in sports is mainly hampered by the following limitations: (1) Previous studies are biased with a focus on young females (Hausenblas \& Carron, 1999; Blaydon \& Lindner, 2002; Torstveit \& Sundgot-Borgen, 2005; Hoch et al., 2007; Rosendahl et al., 2009; Martinsen et al., 2010) who seem to carry, per se, an increased risk for developing an eating disorder (Hausenblas \& Carron, 1999; Blaydon \& Lindner, 2002; Torstveit \& Sundgot-Borgen, 2005; Wilson \& Shafran, 2005; Hoch et al., 2007; Rosendahl et al., 2009; Martinsen et al., 2010; Wunderer et al., 2011); and (2) Many studies recruited and analyzed individuals from very different sports, including both endurance and non-endurance activities (e.g., archery and rifle shooting) (Chapman \& Woodman, 2015; Sundgot-Borgen \& Larsen, 1993; Fransen, 1996; Fulkerson et al., 1999; Smolak et al., 2000; Augestad \& Flanders, 2002; Sundgot-Borgen \& Torstveit, 2004; Torstveit \& SundgotBorgen, 2005; Torstveit et al., 2008; Hoch et al., 2009; Rosendahl et al., 2009; Martinsen et al., 2010). To overcome these limitations of the existing literature, a broad spectrum of athletes were investigated, further categorized by activity status, age and sex, and focused on endurance sports. Moreover, the well-validated SCOFF test was employed that shows high sensitivity (84.6\%) and specificity (89.6\%) in general practice (Morgan et al., 1999; Luck et al., 2002; Hill et al., 2009).

In this study, 195/1031 participants (18.9\%) were SCOFF positive, indicating that they are at risk for developing an eating disorder. This result corresponds to the KiGGS study ("Kinder-und Jugendgesundheitssurvey") (Holling et al., 2007) that showed a prevalence of $21.9 \%$ among German teenagers between ages eleven to sixteen years, although the present sample contained participants with an average age of 42 years. Research using other study methods often shows a lower prevalence for eating disorders. The cause for this phenomenon is the design of the SCOFF questionnaire, created as a screening tool with the highest possible sensitivity (Luck et al., 2002). The high negative predictive value of $99.3 \%$ and the low positive predictive value of $24.4 \%$ suggest that the SCOFF test tends to overrate individuals at risk (Morgan et al., 1999; Luck et al., 2002; Hill et al., 2009). Additionally the SCOFF is validated as a test for general health. Examining athletes especially the questions "Have you recently lost more than one stone (15 pounds) in a 3 month period?" and "Would you say that food dominates your life?" tend to overrate, too. Nonetheless, two positive answers indicate disordered eating behaviour and attitudes (Morgan et al., 1999; Luck et al., 2002; Hill et al., 2009). Therefore, the SCOFF questionnaire was the ideal instrument for examining a group of more than 1000 participants providing their information voluntarily, also leading to the high response rate of $92.1 \%$. In addition, and as mentioned earlier, the SCOFF is a highly validated instrument (Luck et al., 2002).

The significantly higher rate among participants between 21 and 25 years is consistent with other reports in the literature (Hoek \& van Hoeken, 2003; Van Son et al., 2010; Smink et al., 2012; Van Son et al., 2012; Smink et al., 2013). The fact that the group from 18 to 20 years did not have a significantly higher rate is likely based on the small number of participants (18/1031 corresponding to $1.7 \%$ of the whole sample).

Unlike the results published in many studies (Wittchen et al., 1998; Hudson et al., 2007; Nice-Guidelines, 2009), a significant difference between male and female athletes in developing eating disorders was not found. Although this observation clearly deserves further experimental investigation, it suggests that endurance sports might be a risk factor for developing an eating disorder in male but not female athletes.

We discriminated elite and hobby athletes by the event in which they participated. We considered athletes taking part at national championships, including the Challenge Roth Triathlon and German Championships Marathon Running, as elite athletes, while others taking part at a $10 \mathrm{~km}$ hobby run without timing were most likely hobby athletes. Although this approach was very pragmatic, we believe it allowed us to not only categorize athletes by training hours but by the motivation with which the athletes participated. Based on this categorization, we didn't observe any significant differences neither between elite and hobby athletes nor between runners and other endurance sports for developing an eating disorder, by contrast to the results published by Sundgot-Borgen (Sundgot-Borgen \& Torstveit, 2004). This is of particular interest because leanness is a key success factor for runners (Marriott \& Grumstrup-Scott, 1992; Boileau \& Horswill, 2000). This may give rise to speculations that the willingness to succeed is not a risk factor for developing an eating disorder, even in sports where weight is an important factor of ranking. Of note, this observation is in agreement with other reports that found an even higher prevalence for eating disorders among teenage non-athletes compared to athletes (Rosendahl et al., 2009; Martinsen et al., 2010). Of note, we did not observe a link between training quantity (hours per week and train- 
ing lessons per week) with eating disorders, but an association with endurance addiction as reported in literature (Chapman \& De Castro, 1990; MacLaren \& Best, 2007).

In this work, overweight or even obese athletes were at higher risk for developing an eating disorder according to the SCOFF test. The small number of obese participants (22/1073 corresponding to 2.2\%), however, does not allow final conclusions. Assuming that the higher risk for developing eating disorders among obese athletes can be confirmed by future studies, the following interpretations appear to be plausible: First, obese individuals might be prone to score positive for the following assessment: "Would you say that food dominates your life?"; Secondly, a weight loss of more than one stone in a three month period might be even considered beneficial among obese participants who begin exercising.

The significantly higher percentage of participants at risk for developing eating disorders who are in vocational training can be attributed to the age distribution and the fact that most people in vocational training are younger than 30 years of age.

The very low Cronbach Alpha was expected. The SCOFF questionnaire consists of 5 diametric questions and was constructed to indicate all kinds of eating disorders, which show big differences (e.g., between binge eating and anorexia nervosa).

In the current study, 27/999 (2.7\%) scored at least 24 points in the Exercise Addiction Inventory, indicating exercise dependency. The rate of exercise dependency among endurance sportsmen in the available literature ranges from 3 all the way up to 52\% (Blaydon \& Lindner, 2002; Griffiths et al., 2005; Edmunds et al., 2006). Several explanations might account for these striking differences (de Coverley Veale, 1987; Szabo, 2000; Szabo, 1997): Difficulties in separating exercise dependence from exercise commitment might have led to the high percentages of exercise dependency in a number of studies. Moreover, further (non-endurance) sports studied by other investigators might be subject to different aetiologies and levels of exercise addiction.

Other than Pierce (Pierce et al., 1993), no difference was seen between the type of endurance sports nor between hobby and elite athletes. There was also no difference between runners and persons engaging in other types of sports with respect to the number of subjects at risk of developing exercise dependence. Additionally, in this study's sample, other than the examination of 408 university students by Hausenblas (Hausenblas \& Downs, 2002) who found more male subjects being exercise dependant, or Pierce (Pierce et al., 1997) who found women scoring significantly higher scores on an exercise dependence survey among 32 marathon road racers, no gender difference in the risk for developing an exercise addiction.

The relatively low Cronbach Alpha should be due to the brief screening tool with only 6 questions and the goal to indicate as many symptoms of addiction as possible. Thus, the questionnaire shows a high bandwidth but only the relatively low reliability (bandwidth fidelity dilemma).

12 of 27 (44.4\%) participants scoring EAI positive were also at risk for developing an eating disorder, indicating a strong correlation between exercise dependence and eating disorders $\left(\chi^{2}=9.3, \mathrm{df}=1, \mathrm{p}<0.01\right)$. Here, it can be postulated that exercise dependence is secondary to the eating disorder. On the other hand, $54.6 \%$ of participants that were seen to score EAI positive were, in fact, SCOFF negative, suggesting that primary exercise dependence is an existing phenomenon and makes up about half of all exercise-dependent patients, also observed by other authors (Bamber et al., 2000; Blaydon \& Lindner, 2002; Bratland-Sanda et al., 2010). The high co-morbidity of exercise dependence and eating disorders seems to be in parallel with the fact that endurance sports can contribute to decreasing body weight and are associated with the same risk factors for developing exercise dependence or eating disorders such as an obsessive-compulsive personality (Edmunds et al., 2006; Sansone \& Sansone, 2010). The relatively weak Cramer-V should be due to the high number of subjects scoring positive for eating disorders compared with the relatively small number of subjects scoring positive for exercise addiction.

This present study had certain restrictions: In order to interview as many participants as possible at each event and obtain a cross-section, rapid screening assessments (i.e., less than $10 \mathrm{~min}$ ) were used for exercise addiction and disordered eating in endurance sports. Extensive interviews were not performed to study personality types amongst other characteristics of the individuals, which might have given more precise estimates of exercise dependence and eating disorders. As it was impossible within the given setting to recruit a sufficient number of professional athletes whose incomes depend on competition earnings, the quality of the event was utilized to divide high performers (elites) and hobby athletes. For logistical reasons, events in Southern Germany were focused on and German speakers were included specifically by using questionnaires in German language. With the goal of involving as many participants as possible, after each event, every single participant was approached. 
However, there was no ability to document how many denied participating in our study. Participants were randomly asked in the finisher areas. Especially when many athletes reached the finish line the same time it was not possible to ask all finishers. For measuring body composition we used the well-known BMI which is not exact. So different populations with the same degree of body fat result in different BMI scores, e.g. at the same BMI Blacks have lower body fat than Whites and athletes have lower body fat than non-athletes due to the different body composition with a higher proportion of muscles compared with body fat. Unfortunately there is no validation for BMI cut-offs for athletes.

\section{Summary}

With a rate of $18.9 \%$ being at risk for developing an eating disorder, eating disorders seem to be a major problem in general practice.

Eating disorders do not appear to be more common in endurance sports athletes than in the general population, thus these types of sports cannot be considered as risk factors for developing one.

As reported by others, equal numbers of male and female participants at risk for developing an eating disorder were seen.

In general, one might come to the reasonable conclusion that an eating disorder should be kept in mind if the patient either has an abnormal BMI or endurance sports are practiced excessively, especially in male patients.

A prevalence of exercise dependence among endurance athletes of $2.7 \%$ is consistent with most of the data reported in the literature.

There is a strong correlation between disordered eating and exercise dependence.

Primary exercise dependence is a real diagnosis and constitutes about half of all exercise-dependent patients.

Therefore, primary care takers as well as sport coaches should be vigilant about eating disorders and exercise addiction in both elite and amateur athletes.

\section{Acknowledgements}

The present work was performed in fulfillment of the requirements for obtaining the degree "Dr. med."

The authors declare that there is no conflict of interests.

\section{References}

Ascensao, A., Ferreira, R. et al. (2007). Exercise-Induced Cardioprotection-Biochemical, Morphological and Functional Evidence in Whole Tissue and Isolated Mitochondria. International Journal of Cardiology, 117, 16-30. http://dx.doi.org/10.1016/j.ijcard.2006.04.076

Augestad, L. B., \& Flanders, W. D. (2002). Eating Disorder Behavior in Physically Active Norwegian Women. Scandinavian Journal of Medicine \& Science in Sports, 12, 248-255. http://dx.doi.org/10.1034/j.1600-0838.2002.00390.x

Bamber, D., Cockerill, I. M. et al. (2000). The Pathological Status of Exercise Dependence. British Journal of Sports Medicine, 34, 125-132. http://dx.doi.org/10.1136/bjsm.34.2.125

Blaydon, M. J., \& Lindner, K. J. (2002). Eating Disorders and Exercise Dependence in Triathletes. Eating Disorders: The Journal of Treatment \& Prevention, 10, 49-60. http://dx.doi.org/10.1080/106402602753573559

Bo, H., Jiang, N., Zhang, Z. Y., Ji, L. L., \& Zhang, Y. (2014). Exercise and Health: From Evaluation of Health-Promoting Effects of Exercise to Exploration of Exercise Mimetics. Progress in Physiology, 45, 251-256.

Boileau, R. A., \& Horswill, C. A. (2000). Exercise and Sports Science. Philadelphia, PA: Lippincott Williams \& Wilkins.

Bratland-Sanda, S., Sundgot-Borgen, J., Rø, Ø., Rosenvinge, J. H., Hoffart, A., \& Martinsen, E. W. (2010). Physical Activity and Exercise Dependence during Inpatient Treatment of Longstanding Eating Disorders: An Exploratory Study of Excessive and Non-Excessive Exercisers. International Journal of Eating Disorders, 43, 266-273.

Brown, R. I. F. (1993). Some Contributions of the Study of Gambling to the Study of Other Addictions. In Gambling Behaviour and Problem Gambling (pp.241-272). Reno: University of Nevada Press.

Busanich, R., McGannon, K.R., \& Schinke, R.J. (2014). Comparing Elite Male and Female Distance Runner's Experiences of Disordered Eating through Narrative Analysis. Psychology of Sport and Exercise, 15, 705-712. http://dx.doi.org/10.1016/j.psychsport.2013.10.002

Chapman, C. L., \& De Castro, J. M. (1990). Running Addiction: Measurement and Associated Psychological Characteristics. The Journal of Sports Medicine and Physical Fitness, 30, 283-290.

Chapman, J., \& Woodman, T. (2015). Disordered Eating in Male Athletes: A Meta-Analysis. Journal of Sports Sciences, 34, 101-109. 
de Coverley Veale, D. M. (1987). Exercise Dependence. British Journal of Addiction, 82, 735-740. http://dx.doi.org/10.1111/j.1360-0443.1987.tb01539.x

Declaration of Helsinki. Retrieved 02/14/2008, 2012. http://www.wma.net/e/ethicsunit/helsinki.htm

Dirmaier, J., Krattenmacher, T., Watzke, B., Koch, U., Schulz, H., \& Barghaan, D. (2010). Evidence-Based Treatments in the Rehabilitation of Patients with Depression-A Literature Review. Psychotherapie, Psychosomatik, Medizinische Psychologie, 60, 83-97. http://dx.doi.org/10.1055/s-0029-1220887

Edmunds, J., Ntoumanis, N., \& Duda, J. L. (2006). Examining Exercise Dependence Symptomatology from a Self-Determination Perspective. Journal of Health Psychology, 11, 887-903. http://dx.doi.org/10.1177/1359105306069091

Fransen, L. M. (1996). Environmental Pressures, Personality Factors and Their Relationship to Eating Disorders in Elite Female Athletes. Unpublished Doctoral Dissertation, Missoula, MT: University of Montana.

Fulkerson, J. A., Keel, P. K., Leon, G. R., \& Dorr, T. (1999). Eating-Disordered Behaviors and Personality Characteristics of High School Athletes and Nonathletes. International Journal of Eating Disorders, 26, 73-79.

http://dx.doi.org/10.1002/(SICI)1098-108X(199907)26:1<73::AID-EAT9>3.0.CO;2-F

Glazer, J. L. (2008). Eating Disorders among Male Athletes. Current Sports Medicine Reports, 7, 332-337. http://dx.doi.org/10.1249/JSR.0b013e31818f03c5

Greist, J. H., Klein, M. H., Eischens, R. R., Faris, J., Gurman, A. S., \& Morgan, W. P. (1978). Running through Your Mind. Journal of Psychosomatic Research, 22, 259-294. http://dx.doi.org/10.1016/0022-3999(78)90049-1

Greist, J. H., Klein, M. H., Eischens, R. R., Faris, J., Gurman, A. S., \& Morgan, W. P. (1979). Running as Treatment for Depression. Comprehensive Psychiatry, 20, 41-54. http://dx.doi.org/10.1016/0010-440X(79)90058-0

Griffiths, M. D., Szabo, A., \& Terry, A (2005). The Exercise Addiction Inventory: A Quick and Easy Screening Tool for Health Practitioners. British Journal of Sports Medicine, 39, e30. http://dx.doi.org/10.1136/bjsm.2004.017020

Hausenblas, H. A., \& Downs, D. S. (2002). Relationship among Sex, Imagery, and Exercise Dependence Symptoms. Psychology of Addictive Behaviors, 16, 169-172. http://dx.doi.org/10.1037/0893-164X.16.2.169

Hausenblas, H., \& Carron, A. V. (1999). Eating Disorder Indices and Athletes: An Integration. Journal of Sport \& Exercise Psychology, 21, 230-258.

Hausenblas, H., \& Downs, D. S. (2001). How Much Is Too Much? The Development and Validation of the Exercise Dependence Scale. Psychology \& Health, 17, 387-404. http://dx.doi.org/10.1080/0887044022000004894

Hill, L. S., Reid, F., Morgan, J. F., \& Lacey, J. H. (2009). SCOFF, the Development of an Eating Disorder Screening Questionnaire. International Journal of Eating Disorders, 43, 344-351. http://dx.doi.org/10.1002/eat.20679

Hoch, A. Z., Pajewski, N. M., Moraski, L., Carrera, G. F., Wilson, C. R., Hoffmann, R. G., Schimke, J. E., \& Gutterman, D. D. (2009). Prevalence of the Female Athlete Triad in High School Athletes and Sedentary Students. Clinical Journal of Sport Medicin, 19, 421-428. http://dx.doi.org/10.1097/JSM.0b013e3181b8c136

Hoch, A. Z., Stavrakos, J. E., \& Schimke, J. E. (2007). Prevalence of Female Athlete Triad Characteristics in a Club Triathlon Team. Archives of Physical Medicine and Rehabilitation, 88, 681-682. http://dx.doi.org/10.1016/j.apmr.2007.02.035

Hoek, H. W., \& van Hoeken, D. (2003). Review of the Prevalence and Incidence of Eating Disorders. International Journal of Eating Disorders, 34, 383-396. http://dx.doi.org/10.1002/eat.10222

Holling, H., Kamtsiuris, P., Lange, M., Thierfelder, W., Thamm, M., \& Schlack, R. (2007). [The German Health Interview and Examination Survey for Children and Adolescents (KiGGS): Study Management and Conduct of Fieldwork]. Bundesgesundheitsblatt, Gesundheitsforschung, Gesundheitsschut, 50, 557-566.

Hudson, J. I., Hiripi, E., Pope Jr., H. G., \& Kessler, R. C. (2007). The Prevalence and Correlates of Eating Disorders in the National Comorbidity Survey Replication. Biological Psychiatry, 61, 348-358. http://dx.doi.org/10.1016/j.biopsych.2006.03.040

Jacobi, C., \& de Zwaan, M. (2006). Essstörungen. In H. U. Wittchen, \& J. Hoyer (Eds.), Klinische Psychologie \& Psychotherapie (pp. 883-909). Heidelberg: Springer-Verlag.

Johnson, C., Powers, P. S., \& Dick, R. (1999). Athletes and Eating Disorders: The National Collegiate Athletic Association Study. International Journal of Eating Disorders, 26, 179-188. http://dx.doi.org/10.1002/(SICI)1098-108X(199909)26:2<179::AID-EAT7>3.0.CO;2-Z

Jorgenson, C. B., \& Jorgenson, D. E. (1979). Effect of Running on Perception of Self and Others. Perceptual and Motor Skills, 48, 242. http://dx.doi.org/10.2466/pms.1979.48.1.242

Karstoft, K., \& Pedersen, B. K. (2015). Exercise and Type 2 Diabetes: Focus on Metabolism and Inflammation. Immunology \& Cell Biology, 94, 146-150. http://dx.doi.org/10.1038/icb.2015.101

Kasch, F. W., Phillips, W. H., Carter, J. E., \& Boyer, J. L. (1973). Cardiovascular Changes in Middle-Aged Men during Two Years of Training. Journal of Applied Physiology, 34, 53-57. 
Kemmler, W., Bebenek, M., Kohl, M., \& von Stengel, S. (2015). Exercise and Fractures in Postmenopausal Women. Final Results of the Controlled Erlangen Fitness and Osteoporosis Prevention Study (EFOPS). Osteoporosis Interna- tional, 26, 2491-2499. http://dx.doi.org/10.1007/s00198-015-3165-3

Kemmler, W., Engelke, K., Baumann, H., Beeskow, C., von Stengel, S., Weineck, J., \& Kalender, W. A. (2006). Bone Status in Elite Male Runners. European Journal of Applied Physiology, 96, 78-85. http://dx.doi.org/10.1007/s00421-005-0060-1

Kim, T. K., Kim, J. E. et al. (2015). Antidepressant Effects of Exercise Are Produced via Suppression of Hypocretin/ Orexin and Melanin-Concentrating Hormone in the Basolateral Amygdala. Neurobiology of Disease, 79, 59-69. http://dx.doi.org/10.1016/j.nbd.2015.04.004

Le Page, K. (2010). Eating Disorders in Sport. Which Sports Are High Risk? http://eatingdisorders.suite101.com/article.cfm/eating-disorders-in-sport

Lejoyeux, M., Avril, M., Richoux, C., Embouazza, H., \& Nivoli, F. (2008). Prevalence of Exercise Dependence and Other Behavioral Addictions among Clients of a Parisian Fitness Room. Comprehensive Psychiatry, 49, 353-358. http://dx.doi.org/10.1016/j.comppsych.2007.12.005

Leonardson, G. R. (1977). Relationship between Self-Concept and Perceived Physical Fitness. Perceptual and Motor Skills, 44, 62. http://dx.doi.org/10.2466/pms.1977.44.1.62

Lion, L. S. (1978). Psychological Effects of Jogging: A Preliminary Study. Perceptual and Motor Skills, 47, 1215-1218. http://dx.doi.org/10.2466/pms.1978.47.3f.1215

Luck, A. J., Morgan, J. F. et al. (2002). The SCOFF Questionnaire and Clinical Interview for Eating Disorders in General Practice: Comparative Study. BMJ, 325, 755-756. http://dx.doi.org/10.1136/bmj.325.7367.755

MacLaren, V. V., \& Best, L. A. (2007). Symptoms of Exercise Dependence and Physical Activity in Students. Perceptual and Motor Skills, 105, 1257-1264. http://dx.doi.org/10.2466/pms.105.7.1257-1264

Maraz, A., Urban, R., Griffiths, M. D., \& Demetrovics, Z. (2015). An Empirical Investigation of Dance Addiction. PLoS ONE, 10, e0125988. http://dx.doi.org/10.1371/journal.pone.0125988

Marriott, B. M., \& Grumstrup-Scott, J. (1992). Body Composition and Physical Performance. Washington DC: National Academy Press.

Martinsen, M., Bratland-Sanda, S., Eriksson, A. K., \& Sundgot-Borgen, J. (2010). Dieting to Win or to Be Thin? A Study of Dieting and Disordered Eating among Adolescent Elite Athletes and Non-Athlete Controls. British Journal of Sports Medicine, 44, 70-76. http://dx.doi.org/10.1136/bjsm.2009.068668

Mayo Clinic Staff (2010). Eating Disorders Risk Factors. http://www.mayoclinic.com/health/eating-disorders/DS00294/DSECTION=risk-factors

Morgan, J. F., Reid, F., \& Hubert Lacey, J. (1999). The SCOFF Questionnaire: Assessment of a New Screening Tool for Eating Disorders. BMJ, 319, 1467-1468. http://dx.doi.org/10.1136/bmj.319.7223.1467

Nice-Guidelines (2009). Depression. The Treatment and Management of Depression in Adults. National Institute for Health and Clinical Excellence.

Palermo, A., Maggi, D., Maurizi1, A. R., Pozzilli, P., \& Buzzetti, R. (2014). Prevention of Type 2 Diabetes Mellitus: Is It Feasible? Diabetes/Metabolism Research and Reviews, 30, 4-12. http://dx.doi.org/10.1002/dmrr.2513

Pasman, L., \& Thomson, J. K. (1988). Body Image and Eating Disturbance in Obligatory Runners, Obligatory Weightlifters, and Sedentary Individuals. International Journal of Eating Disorders, 7, 759-769. http://dx.doi.org/10.1002/1098-108X(198811)7:6<759::AID-EAT2260070605>3.0.CO;2-G

Pierce, E. F., McGowan, R. W., \& Lynn, T. D. (1993). Exercise Dependence in Relation to Competitive Orientation of Runners. The Journal of Sports Medicine and Physical Fitness, 33, 189-193.

Pierce, E. F., Rohaly, K. A., \& Fritchley, B. (1997). Sex Differences on Exercise Dependence for Men and Women in a Marathon Road Race. Perceptual and Motor Skills, 84, 991-994. http://dx.doi.org/10.2466/pms.1997.84.3.991

Pollock, M. L., Dimmick, J., Miller Jr., H. S., Kendrick, Z., \& Linnerud, A. C. (1975). Effects of Mode of Training on Cardiovascular Function and Body Composition of Adult Men. Medicine \& Science in Sports \& Exercise, 7, 139-145.

Roberts, A. J., \& Taplin, C. E. (2015). Exercise in Youth with Type 1 Diabetes. Current Pediatric Reviews, 11, 120-125. http://dx.doi.org/10.2174/1573396311666150702105340

Rosendahl, J., Bormann, B., Aschenbrenner, K., Aschenbrenner, F., \& Strauss, B. (2009). Dieting and Disordered Eating in German High School Athletes and Non-Athletes. Scandinavian Journal of Medical Science in Sports, 19, 731-739. http://dx.doi.org/10.1111/j.1600-0838.2008.00821.x

Ryninks, K., Sutton, E., Thomas, E., Jago, R., Shield, J. P. H., \& Burren, C. P. (2015). Attitudes to Exercise and Diabetes in Young People with Type 1 Diabetes Mellitus: A Qualitative Analysis. PLoS ONE, 10, e0137562. http://dx.doi.org/10.1371/journal.pone.0137562 
Salmon, P. (1991). Running Addiction. British Journal of Hospital Medicine, 46, 17.

Saltin, B., Blomqvist, G., Mitchell, J.H., Johnson Jr., R.L., Wildenthal, K., \& Chapman, C.B. (1968). Response to Exercise after Bed Rest and after Training. Circulation, 38, VII1-78.

Sansone, R. A., \& Sansone, L. A. (2010). Personality Disorders as Risk Factors for Eating Disorders: Clinical Implications. Nutrition in Clinical Practice, 25, 116-121. http://dx.doi.org/10.1177/0884533609357563

Smink, F. R., van Hoeken, D., \& Hoek, H. W. (2012). Epidemiology of Eating Disorders: Incidence, Prevalence and Mortality Rates. Current Psychiatry Reports, 14, 406-414. http://dx.doi.org/10.1007/s11920-012-0282-y

Smink, F. R., van Hoeken, D., \& Hoek, H. W. (2013). Epidemiology, Course, and Outcome of Eating Disorders. Current Opinion in Psychiatry, 26, 543-548. http://dx.doi.org/10.1097/yco.0b013e328365a24f

Smolak, L., Murnen, S. K., \& Ruble, A. E. (2000). Female Athletes and Eating Problems: A Meta-Analysis. International Journal of Eating Disorders, 27, 371-380. http://dx.doi.org/10.1002/(SICI)1098-108X(200005)27:4<371::AID-EAT1>3.0.CO;2-Y

Sundgot-Borgen, J., \& Larsen, A. G. (1993). Pathogenic Weight-Control Methods and Self-Reported Eating Disorders in Female Elite Athletes and Controls. Scandinavian Journal of Medicine \& Science in Sports, 3, 150-155. http://dx.doi.org/10.1111/j.1600-0838.1993.tb00379.x

Sundgot-Borgen, J., \& Torstveit, M. K. (2004). Prevalence of Eating Disorders in Elite Athletes Is Higher than in the General Population. Clinical Journal of Sport Medicine, 14, 25-32. http://dx.doi.org/10.1097/00042752-200401000-00005

Szabo, A. (1997). Relationships between Addiction to Running, Commitment to Running, and Deprivation from Running. European Yearbook of Sport Psychology, 1, 130-147.

Szabo, A. (2000). Physical Activity and Psychological Dysfunction. London: Routledge.

Thopson, R. A., \& Sherman, R. T. (2007). Eating Disorders in Sport: From Theory to Research to Intervention. In G. Tenenbaum, \& R. C. Eklund (Eds.), Handbook of Sport Psychology (pp. 352-378). Hoboken, NJ: John Wiley \& Sons.

Torstveit, M. K., \& Sundgot-Borgen, J. (2005). The Female Athlete Triad Exists in Both Elite Athletes and Controls. Medicine \& Science in Sports \& Exercise, 37, 1449-1459. http://dx.doi.org/10.1249/01.mss.0000177678.73041.38

Torstveit, M. K., Rosenvinge, J. H., \& Sundgot-Borgen, J. (2008). Prevalence of Eating Disorders and the Predictive Power of Risk Models in Female Elite Athletes: A Controlled Study. Scandinavian Journal of Medicine \& Science in Sports, 18, 108-118. http://dx.doi.org/10.1111/j.1600-0838.2007.00657.x

Van Son, G. E., Hoek, H. W., Van Hoeken, D., Schellevis, F. G., \& Van Furth, E. F. (2012). Eating Disorders in the General Practice: A Case-Control Study on the Utilization of Primary Care. European Eating Disorders Review, 20, 410-413. http://dx.doi.org/10.1002/erv.2185

Van Son, G. E., van Hoeken, D., van Furth, E. F., Donker, G. A., \& Hoek, H. W. (2010). Course and Outcome of Eating Disorders in a Primary Care-Based Cohort. International Journal of Eating Disorders, 43, 130-138.

Weik, M., \& Hale, B. D. (2009). Contrasting Gender Differences on Two Measures of Exercise Dependence. British Journal of Sports Medicine, 43, 204-207. http://dx.doi.org/10.1136/bjsm.2007.045138

Wheeler, G. D., Wall, S. R., Belcastro, A. N., Conger, P., \& Cumming, D. C. (1986). Are Anorexic Tendencies Prevalent in the Habitual Runner? British Journal of Sports Medicine, 20, 77-81. http://dx.doi.org/10.1136/bjsm.20.2.77

WHO (2012). BMI Classification. Retrieved June 20, 2012. http://apps.who.int/bmi/index.jsp?introPage=intro 3.html

Williams, J. R. (2008). The Declaration of Helsinki and Public Health. Bulletin of the World Health Organization, 86, 650652. http://dx.doi.org/10.2471/BLT.08.050955

Wilson, G. T., \& Shafran, R. (2005). Eating Disorders Guidelines from NICE. The Lancet, 365, 79-81. http://dx.doi.org/10.1016/S0140-6736(04)17669-1

Winzenberg, T., Oldenburg, B., Frendin, S., De Wit, L., Riley, M., \& Jones, G. (2006). The Effect on Behavior and Bone Mineral Density of Individualized Bone Mineral Density Feedback and Educational Interventions in Premenopausal Women: A Randomized Controlled Trial. BMC Public Health, 6, 12. http://dx.doi.org/10.1186/1471-2458-6-12

Wittchen, H. U., Nelson, C. B., \& Lachner, G. (1998). Prevalence of Mental Disorders and Psychosocial Impairments in Adolescents and Young Adults. Psychological Medicine, 28, 109-126. http://dx.doi.org/10.1017/S0033291797005928

Wunderer, E., Borse, S. et al. (2011). Essstörungen. In D. H. F. Suchtfragen (Ed.), Jahrbuch Sucht 2011 (pp. 128-139). Geesthacht: Neuland.

Yoon, H., Thakur, V., Isham, D., Fayad, M., \& Chattopadhyay, M. (2015). Moderate Exercise Training Attenuates Inflammatory Mediators in DRG of Type 1 Diabetic Rats. Experimental Neurology, 267, 107-114.

http://dx.doi.org/10.1016/j.expneurol.2015.03.006 